\title{
PENERAPAN APLIKASI INTEGRATED STORED SYSTEM SEBAGAI SOLUSI KEMUDAHAN PELAPORAN TRANSAKSI PENJUALAN
}

\author{
Yudo Bismo Utomo', Danang Erwanto ${ }^{2}$, Achmad Arif Alfin ${ }^{1}$, \\ Ahmad Ari Setyawan Kusuma ${ }^{1}$ \\ 1Fakultas Teknik, Teknik Komputer, Universitas Islam Kadiri Kediri \\ 2Fakultas Teknik, Teknik Elektro, Universitas Islam Kadiri Kediri \\ Email :yudobismo@uniska-kediri.ac.id
}

\begin{abstract}
ABSTRAK
Pada era revolusi industri 4.0 saat ini, penerapan sistem informasi yang terintegrasi berbasis Komputer dalam bidang usaha perdagang,,an merupakan hal yang sangat penting, supaya tidak membutuhkan waktu yang lama dalam melayani customer. Salah satu contohnya adalah dalam hal transaksi penjualan. Jika volume transaksi penjualan meningkat dan masih menggunakan sistem manual, maka resikonya adalah pemilik usaha tidak bisa memonitoring transaksi penjualannya. Hal ini dirasakan oleh mitra pengabdian, yaitu Toko Novita. Toko novita ini dalam sehari bisa mencapai 50 transaksi dalam satu hari. Dari permasalahan tersebut diatas, solusi yang ditawarkan oleh tim pengabdian yaitu mengadakan pengabdian tentang pembuatan aplikasi sistem informasi yang terintegrasi berbasis komputer berupa aplikasi integrated stored system yang mampu memonitoring transaksi penjualan, supaya lebih mudah dan sistematis. Langkah pelaksanaan pengabdian dibagi dalam beberapa tahap, yaitu perencanaan, pelaksanaan dan pendampingan. Hasil yang dicapai dari kegiatan pengabdian ini meliputi : 1) memanfaatkan aplikasi integrated store system untuk memonitoring transaksi penjualan supaya lebih mudah dan sistematis, 2) mengurangi potensi kesalahan dalam transaksi penjualan, 3) memberikan ketrampilan dalam penggunaan sistem informasi yang terintegrasi berbasis komputer, dan 4) memperoleh tambahan pengetahuan dalam menerapkan teknologi informasi supaya lebih cepat dan tepat dalam melayani customer. Kata Kunci: sistem informasi, aplikasi integrated stored system, pelaporan transaksi penjualan.
\end{abstract}

\section{PENDAHULUAN}

Dalam sebuah bisnis akan selalu berkaitan dengan penjualan. Pada setiap transaksi bisnis, penjualan merupakan hal yang paling penting. Angka penjualan yang semakin tinggi, berarti semakin tinggi pula laba dan keuntungan yang akan didapatkan oleh pelaku usaha.

Begitu juga untuk bisnis yang sudah dibangun oleh Toko Novita sebagai mitra pengabdian yang berlokasi di Nganjuk Jawa Timur. Bisnis Toko Novita ini bergerak dibidang konveksi, yaitu menjual pakaian anak-anak. Pada saat ini, bisnis konveksi merupakan salah satu bisnis yang berkembang, dikarenakan pakaian merupakan salah satu kebutuhan dasar dari setiap umat manusia. 
Dalam transaksi bisnisnya, Toko Novita ini masih menggunakan cara manual, yaitu pencatatan transaksi penjualan menggunakan nota kuitansi. Cara manual dapat dilakukan oleh mitra jika data yang diolah sedikit, akan tetapi pada kenyataannya dalam transaksi penjualannya Toko Novita ini hampir setiap hari bisa sampai 50 transaksi, sehingga dapat menyebabkan kesalahan dalam pengolahan data. Permasalahan itu yang sedang dialami oleh mitra saat ini.

Padahal di era revolusi industri 4.0 saat ini, penerapan sistem informasi yang terintegrasi berbasis Komputer dalam pelaku bidang usaha perdagangan konveksi pakaian merupakan hal yang sangat penting, supaya tidak membutuhkan waktu yang lama dalam melayani customer.

Sebagai wujud ikut serta dalam mengembangkan IPTEK di Perguruan Tinggi, maka kami berinisiatif pada kegiatan pengabdian kepada masyarakat kali ini mengadakan kegiatan dengan tema penerapan aplikasi integrated stored system sebagai solusi kemudahan pada saat pelaporan transaksi penjualan, sehingga dengan adanya aplikasi tersebut pelaporan menjadi mudah dan efisien dalam memonitoring transaksi penjualan.

Manfaat lain, dengan adanya aplikasi integrated stored system dapat menanggulangi kesalahan yang masih sering terjadi dalam hal pelaporan transaksi penjualan pada saat mitra masih menggunakan cara manual.

\section{METODE PELAKSANAAN KEGIATAN PENGABDIAN}

Metode pelaksanaan dalam kegiatan pengabdian masyarakat ini, meliputi perencanaan, pelaksanaan dan pendampingan. Dari ketiga metode pelaksanaan tersebut dilakukan dengan beberapa tahap dengan urutan sebagai berikut:

1. Pada tahap pertama dilakukan survey lapangan. Pada tahap ini kami melakukan wawancara mengenai hal-hal yang menjadi kendala yang dihadapi oleh mitra dalam melayani customer-nya, kemudian kita melakukan pengkajian terhadap permasalahan yang sedang dihadapi oleh mitra tersebut. 


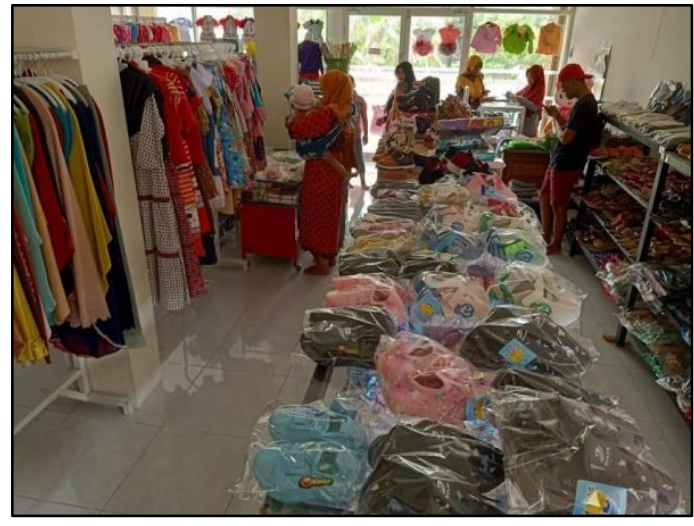

Gambar 1. Kondisi Mitra Pengabdian

2. Tahap kedua mengadakan sosialisasi tentang pentingnya pemanfaatan teknologi informasi. Pada tahap ini dilakukan sosialisasi sebanyak dua kali, dimana peserta sosialisasi ini adalah owner dari Toko Novita dan beberapa pegawainya. Hasil dari sosialisasi ini adalah semua peserta antusias dalam mengikuti sosialisasi ini, dikarenakan mendapatkan ilmu baru mengenai pentingnya teknologi informasi di bidang usaha perdagangan dalam melayani customer.

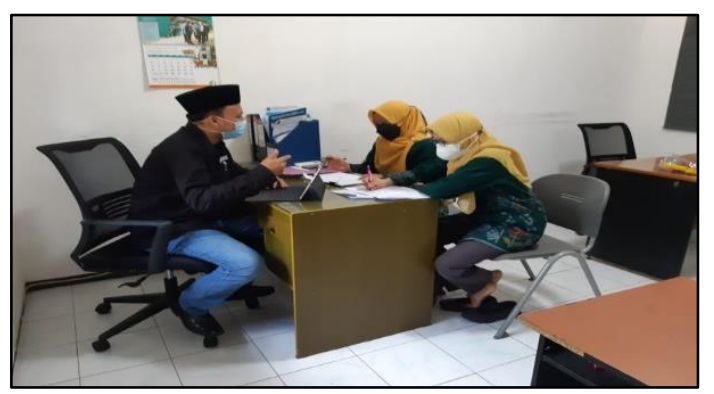

Gambar 2. Tahap Sosialisasi
3. Setelah dilakukan sosialisasi, pada tahap ketiga adalah pembuatan aplikasi integrated stored system yang berbasis komputer, dimana aplikasi ini dibuat menggunakan visual basic dipadukan dengan database php my admin atau lebih dikenal dengan xampp dan untuk data laporannya menggunakan data environment.

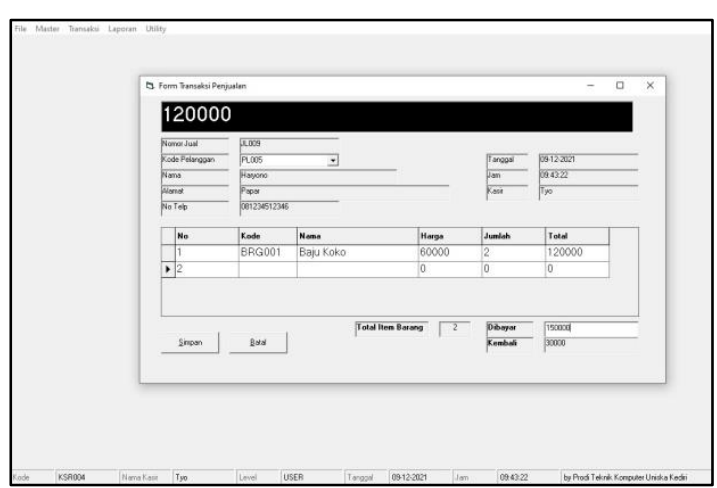

Gambar 3. Aplikasi Integrated Stored System

4. Setelah pembuatan aplikasi integrated stored system sudah selesai dibuat oleh tim, maka tahap terakhir adalah pendampingan dalam mengoperasikan aplikasi tersebut. Pada tahap pendampingan ini dilakukan sebanyak 2 kali. 


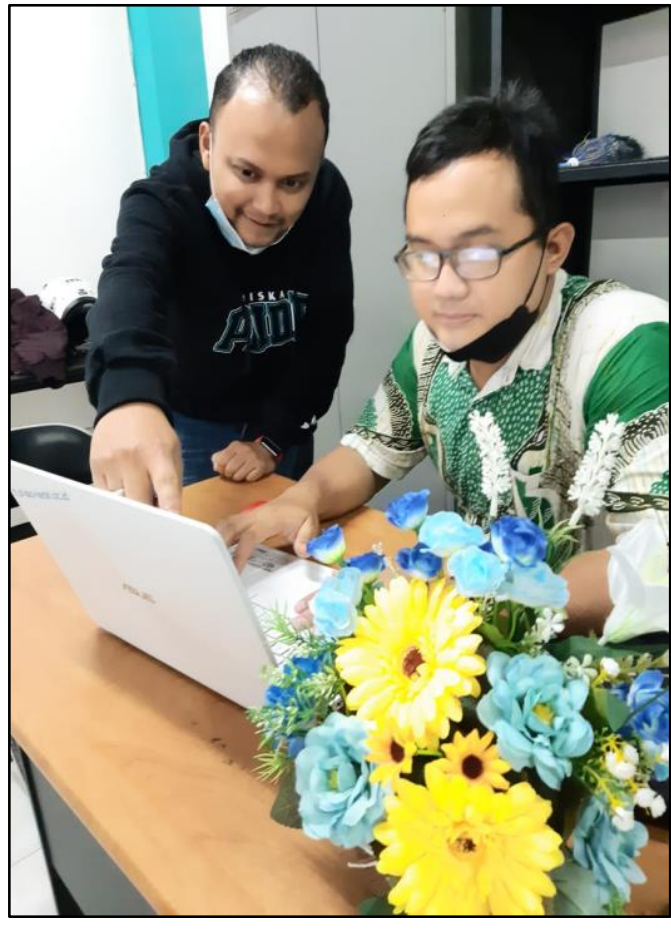

Gambar 4. Tahap Pendampingan

\section{HASIL PELAKSANAAN}

\section{KEGIATAN}

Hasil yang dicapai dalam program pengabdian kepada masyarakat ini adalah sebagai berikut :

1. Memanfaatkan aplikasi integrated store system untuk memonitoring transaksi penjualan, dikarenakan aplikasi ini dilengkapi dengan pelaporan yang bisa dicetak, supaya mitra pengabdian lebih mudah untuk memonitoring dan lebih sistematis.

2. Mengurangi potensi kesalahan dalam transaksi penjualan, dikarenakan aplikasi ini dilengkapi dengan pelaporan item data barang, data pelanggan dan data transaksi penjualan.

3. Memberikan ketrampilan dalam penggunaan sistem informasi yang terintegrasi berbasis komputer.

4. Memperoleh tambahan pengetahuan dalam menerapkan teknologi informasi supaya lebih cepat dan tepat dalam melayani customer.

\section{KESIMPULAN}

Kesimpulan yang dapat diambil dari kegiatan pengabdian masyarakat yang telah dilaksanakan adalah dengan menerapkan aplikasi integrated stored sytem, telah membantu mitra dalam mengurangi resiko potensi kesalahan dalam transaksi penjualan serta dapat memonitoring pelaporan transaksi penjualan secara mudah dan sistematis.

\section{DAFTAR PUSTAKA}

Astuti, P.D . 2013. Sistem Informasi Penjualan Obat Pada Apotek Jati Farma Arjosari, Indones. J. Comput. Sci. - Speed 15, vol. 10, no. 1, pp. 140-145.

Aulia Rahman, Budi Setiadi, Dian Agustini dan Muthia Farida. 2020. Pemanfaatan Teknologi Informasi Menggunakan Aplikasi Edmodo Untuk Guru Dan Siswa Sebagai Media Pembelajaran Pada SMK Muhammadiyah 4 Al-Amin Banjarmasin. Jurnal Pengabdian 
Al-Ikhlas. Vol.6 No.2, pp. 170174.

Bhasin, H., Khanna, and Sudha. 2014. Black Box Testing based on Requirement Analysis and Design Specifications Int. J. Comput. Appl. (0975 - 8887), vol. 87, no. 1, pp. 36-40.

Deviana, H. 2011. Penerapan XML Web service Pada Sistem
Distribusi Barang. J. Geneic, vol. 6, no. 2.

LPKBM MADCOMS. 2005. Aplikasi Manajemen Database Pendidikan Berbasis Web dengan PHP dan MySQL. Madiun: Andi.

Pressman, S.R., Software Engineering : A Practitioner's Approach. Yogyakarta: ANDI and McGrawHill Book Co, 2002. 